\title{
Värikasveista ja kuminasta tuotteiksi
}

\section{Tuotantoketju uusien kasvien viljelystä sekundääriaineiden hyödyntämiseen - esimerkkeinä morsingon (Isatis tinctoria) indigo ja kuminan (Carum carvi) haihtuvat öljyt}

\author{
Marjo Keskitalo Maa- ja elintarviketalouden tutkimuskeskus, Kasvinviljely ja biotekniikka, 31600 \\ Jokioinen, marjo.keskitalo@mtt.fi
}

\section{Johdanto}

Kiinnostus kasvien sekundääriaineisiin ja niiden hyödyntämiseen on lisääntynyt. Metaboliatuotteiden lähteistä, biosynteesireiteistä, analytiikasta, eristyksestä, vaikutusmekanismeista ja hyödyntämismahdollisuuksista tiedetäänkin enemmän kuin kymmenen vuotta sitten. Esimerkiksi funktionaalisiin elintarvikkeisiin liittyvä tutkimus on lisännyt tietoa ja kiinnostusta ruuan terveellisyyteen ja samalla parantanut kuluttajien tietoa aikaisemmin tuntemattomista sekundääriaineista.

Uutena kysymyksenä on syntynyt ajatus, miten erikoiskasvit ja niistä saatavat hyötyaineet voisivat parantaa maaseudun elinvoimaisuutta tai jopa luoda maatiloille erikoistumismahdollisuuksia. Nykyisin viljelijä tuottaa raaka-aineen, josta teollisuudella on tietoa ja valmiuksia eristää kasvikomponentteja hyvinkin erilaisia käyttökohteita varten. Raaka-aineen tuottajalle kasvien tuhansista sekundääriaineista on harvemmin kuitenkaan ollut taloudellista etua.

Morsinko (Isatis tinctorioa) on ristikukkainen ja kaksivuotinen kasvi, joka tuottaa ensimmäisenä vuotena lehtiruusukkeen ja toisena vuotena kukkii keltaisena ja muodostaa siemenet. Lehdet sisältävät esiasteita, joista veteen uuttamisen jälkeen voidaan tuottaa sinistä indigoa (Stoker ym 1998). Indigoa on vuosituhansien ajan käytetty muun muassa tekstiilien värjäykseen. Indigo on ollut myös kullan arvoinen kauppatavara, koska luonnossa on vähän sinisen värin lähteitä. Morsinko, väritatar (Polygonum tinctorum) ja niin kutsuttu indigo-kasvi (Indigofera sp.) ovat tunnetuimmat. Synteettinen indigo syrjäytti kasviindigon tuotannon, käytön sekä värjäyskulttuurin 1800-luvun lopulla (Balfour-Paul 1998).

Kumina (Carum carvi) on sarjakukkainen yksi- tai kaksivuotinen kasvi. Suomessa viljeltävä kaksivuotinen muoto tuottaa ensimmäisenä vuotena lehtiruusukkeen ja toisena vuotena kukkii ja muodostaa siemenet. Yksivuotinen kukkii jo ensimmäisenä vuotena. Siemenet sisältävät haihtuvia öljyjä, joita on perinteisesti käytetty vatsa- ja ilmavaivojen hoidossa, säilönnässä, elintarvikkeiden ja juomien maustamiseen. Kuminan haihtuva öljy sisältää S-karvonia ja S-limoneeniä, joista erityisesti karvonilla on havaittu olevan perunan itämistä ja mikrobien kasvua estävää vaikutusta (Oosterhaven ym. 1995).

MTT:n morsinko- ja kuminatutkimukset käsittävät ketjun viljelystä sekundääriaineiden käyttökohteiden selvittämiseen. Perinteistä poiketen, kasvintuotantoon liittyvä tutkimus sisältää myös aineenvaihduntatuotteiden erotusta, prosessointia sekä aineiden hyödyntämistä. Tutkimusten tarkoituksena on ollut tuottaa tietoa uusien kasvien viljelyn lisäksi myös siitä, mihin kasvien tuottamat sekundääriaineet soveltuvat. Näin on haluttu luoda tutkimuksellista rajapintaa kasviaineita tutkiviin tai käyttäviin yhteistyökumppaneihin. Viljelytekniikoiden lisäksi kiinnostuksena on ollut kehittää sekundääriaineiden erotusmenetelmiä maatilalla tai pienyrityksissä tehtäväksi.

\section{Aineisto ja menetelmät}

Indigotutkimuksissa selvitettiin kenttä- tai kasvihuoneoloissa morsingon viljelytekniikkaa kuten kylvön ajoittamista, siemenmäärän käyttöä, kastelun merkitystä, taimettumista, rikkakasvien hallintaa, sadonkorjuun ajoitusta ja korjuiden määrää, kasvien talvehtimista, siemensadon muodostumista sekä eri kantojen vaihtelua. Myös väritattaren viljelytekniikkaa tutkittiin. Laboratoriossa tutkittiin indigon ja sen esiasteiden määritysmenetelmiä, sadon indigopitoisuuksia, uuttoveden lämpötilan vaikutusta indigon tuottoon, indigon sähkökemiallista pelkistysmenetelmää sekä indigon värjäystä ja kankaan värinkestoa. Pilot-mitassa selvitettiin indigon erotusta lehdistä. Yhteistyökumppanimme selvittivät indigoväriliemen käyttömahdollisuuksia pellava- ja villalankojen tai/ja kankaiden värjäykseen. He myös suunnittelivat ja valmistivat vaatteita ja sisustustekstiilejä värjätyistä raaka-aineista. Tutkimus perustuu SPINDIGO- 
sustainable production of plant-derived indigo -EU-hankkeeseen (www.spindigo.net), jossa ovat MTT Kasvinviljely ja biotekniikan lisäksi mukana myös Englanti, Saksa, Italia ja Espanja. Kansallisesti teimme yhteistyötä Helsingin yliopiston kotitalous- ja käsityötieteen laitoksen, Espoon Vantaan muotoiluinstituutin (EVTEK) sekä Wetterhoff Oy:n, Lainkolan-värjäämön ja Jokipiin Pellava Oy:n kanssa.

Haihtuvien öljyjen tutkimuksissa selvitettiin kuminalajikkeita ja viljelytekniikkaa; sadon laatua; kuminaöljyjen pitoisuuksia ja laatua; haihtuvien öljyjen erotusmenetelmiä; sivutuotteiden laatua; eri menetelmin tuotettujen haihtuvien öljyjen biologista tehoa rikkakasvien torjuntaan, vihannesten varastotauteihin, perunaruttoon, puutavaran suojaukseen ja pikkuporsaiden ruokintaan; ja haihtuvien öljyjen formulointia. Tutkimuksia tehtiin laboratorio-, kasvihuone- ja kenttäkokeina ja kuminaöljyn erotusta siemenistä tehtiin myös pilot-mitassa. Tutkimuksissa käytettiin sekä kaksi- että yksivuotista kuminaa. Vuodesta 1997 lähtien tehdyissä tutkimuksissa on mukana ollut tutkijoita MTT Kasvinviljely ja biotekniikan lisäksi muista MTT:n tutkimuksista (MTT Alueellinen tutkimus, MTT Kasvinsuojelu, MTT Taloustutkimus), Helsingin yliopiston soveltavan biologian laitokselta, Perunantutkimuslaitokselta, VTT:stä sekä Lavalin yliopistosta (Kanada).

\section{Tulokset ja tulosten tarkastelu}

Siemen tai lehtisato Morsinkokokeista korjatut ja hehtaaria kohti lasketut tuoresadot olivat vuosina 20012003 noin $10000-25000 \mathrm{~kg}$. Väritattarin tuorehehtaarisadot olivat vuonna 2003 noin $13000-200000$ kg:a. Siemenmäärän optimoinnilla, tasaisen taimettumisen aikaansaamisella, typpilannoituksella, rivivälien harauksella, sadetuksella ja korjuun optimiajoituksella oli edullinen vaikutus morsingon tuoresatoon. Väritattarin tuoresatoa lisäsi kentän perustaminen esikasvatetuista taimista, kasvukauden lämpötila sekä riittävän veden saanti (Mäkinen 2003). Vuosina 1997 - 2001 tehtyjen kuminakokeiden hehtaarisadot vaihtelivat 600 - 2500 kg:n välillä. Lajikevalinta, typpilannoitus, siemenmäärä, satovuosi ja koepaikka vaikuttivat satoihin (Sammallahti 2001). Kuminaöljyn mahdollista tuotteistaminen on esitetty kuvassa 1.

Sadon sekundääriainepitoisuus Morsinkolehdistä eristetyn indigon pitoisuudet vaihtelevat varsin paljon. Indigopitoisuudet olivat korkeita nuorissa ja pienikokoisissa lehdissä (Keskitalo 2002a). Vuonna 2003 indigopitoisuudet olivat ensimmäisen sadonkorjuun yhteydessä noin $400-550 \mathrm{mg} / \mathrm{kg}$ ja toisen korjuun yhteydessä noin $250-800 \mathrm{mg} / \mathrm{kg}$ tuorepainoa kohti Korkeimmat pitoisuudet toisen korjuun yhteydessä saatiin koejäsenistä, joiden lehdet olivat pienikokoisia. Lehtien kuiva-aine pitoisuudet olivat yleensä $18-23 \%$, joten kuiva-ainetta kohden indigopitoisuudet olivat $4-6$ kertaa suuremmat. Väritattaren lehden indigopitoisuudet olivat 2-4 kertaa morsingon indigopitoisuuksia suurempia (Mäkinen 2003). Kuminan haihtuvan öljyn pitoisuudet olivat kuiva-ainetta kohti noin $30-60 \mathrm{ml} / \mathrm{kg}$, mikä vastaa noin $27-54 \mathrm{~g} / \mathrm{kg}$. Pitoisuuteen vaikuttivat lajike, typpilannoitus ja satovuosi (Keskitalo 2001). Kuminan haihtuvasta öljystä 50 - $80 \%$ oli karvonia, 3 - $5 \%$ muita terpeenejä ja loppuosa limoneeniä (Keskitalo 2001, Sammallahti 2001).

Sekundääriaineiden erotus Indigo esiintyy kasveissa esiasteina, jotka morsingolla ovat isataani B ja indikaani. Vesiliukoiset esiasteet uutetaan yleensä kuumaan veteen (Stoker ym. 1998). Hankkeessa on kehitetty kuumaa vettä käyttävä ja maatilalle soveltuva pilot-laitteisto esiasteiden eristämiseksi. Laitteen avulla tuotetun väriliemen indigopitoisuus oli MTT:ssä noin $50-200 \mathrm{mg} / \mathrm{kg}$. Pitoisuuden alhaisuuteen saattoi vaikuttaa liian suuri lehtimäärä käytettyä vesilitraa kohti, jolloin tiukasti kasassa olleesta lehtimassasta esiasteet eivät uuttuneet veteen. Energian säästämiseksi tutkimme esiasteiden uuttamista myös viileään veteen. Pitoisuudet olivat korkeimmillaan noin $400 \mathrm{mg} / \mathrm{kg}$ tuorepainoa kohti. Silloin inkubointiaika kuitenkin piteni piteni (Viljanen 2004). Viileän veden käytöllä olisi etuna myös se, että vaadittavat laitteet ovat silloin yksinkertaisia. Eristyksen jälkeen liemi varastoidaan kylmiössä tai vaihtoehtoisesti saostetaan ja poistetaan vesi. Kuivana indigokakkuna väri säilyy pitkään. Kokemuksemme mukaan väriliemi tulee kuitenkin käyttää muutaman kuukauden kuluttua valmistuksesta. Kuminan terpeeniset sekundääriaineet ovat öljyliukoisia. Puhdasta kuminan haihtuvaa öljyä tuotettiin maatilalle soveltuvien vesihöyrytislauksen ja puristusmenetelmien avulla (Keskitalo 2002b).

Sekundääriainesato Hehtaarilta laskettu sekundääriainesato riippuu siemen- tai lehtisadon suuruudesta sekä sadon sekundääriainepitoisuudesta. Suuri siemen- tai lehtisato ei takaa aina suurta sekundääriainesatoa. Laskennallisesti morsinko tuotti raaka-indigoa parhaimmillaan $40 \mathrm{~kg} / \mathrm{ha}$, jolloin indigon puhtaus voi korjeintaa olla $30 \%$. Puhdasta indigoa morsinko voi siten tuotaa noin $5000-12.5$ 
$\mathrm{kg} / \mathrm{ha}$. Kuminan haihtuvaa öljyä voitiin laskennallisesti tuottaa $40-80 \mathrm{~kg} / \mathrm{ha}$ riippuen siemenen öljypitoisuudesta sekä siemensadosta (Keskitalo 2002b, Sammallahti 2001).

Sekundääriaineiden prosessointi Indigo on niin kutsuttu kyyppiväri, joka tulee pelkistää ennen värjäystä. Tällä hetkellä sekä synteettinen että kasviperäinen indigo pelkistetään natriumditioniitilla, joka voi olla haitallinen jätevesiin joutuessaan. Kemikaalin avulla aikaansaadun pelkistyksen sijaan etsitään ympäristöystävällisempiä pelkistysmenetelmiä. Tutkimamme sähkökemiallinen pelkistys näyttääkin lupaavalta (Vuorema ym. 2004). Kuminan haihtuvien öljyjen haittana on puolestaan aineiden haihtuvuus. Tutkimustemme mukaan sopivien lisäaineiden avulla voitiin öljyjen haihtuvuutta vähentää.

Sekundääriaineiden teho ja käyttö Tuotettu väriliemi todettiin soveltuvan värjäämöissä käytettäväksi. Koska väriliemen tuotannossa käytettiin melko suurta vesimäärää lehtikiloa kohti, jäi liemen väripitoisuus ja myös värjäyksessä aikaansaadut värisävyt vaaleiksi. Tummien värisävyjen aikaansaamiseksi tulee uuttoveden ja käytetyn lehtimäärän suhdetta tarkistaa. Väriliemellä värjättyjen villakankaiden valon, hankauksen ja pesunkestot olivat hyviä ja verrannollisia synteettisen indigon värinkestoihin (Mussaari 2003). Värjätyistä langoista kudottiin sisustustekstiilejä, joiden suunnittelu oli tehty EVTEK:ssä. Oppilaitoksen opiskelijat suunnittelivat myös indigovärjätyistä kankaista miesten ja naisten vaatteita (Alanen \& Gröhn 2003). Uuden ja ympäristöystävällisemmän sähköä hyödyntävän pelkistysmenetelmän kehittäminen voisi entisestään lisätä kiinnostusta erityisesti ekologisten tekstiilien valmistuksessa. Kuminan haihtuvien öljyjen tehotutkimuksissa lupaavia tuloksia saatiin öljyn käytöstä muun muassa sienitautien ja perunaruton hillitsemiseksi (Westerback 1999, Hannukkala ym. 2001). Myös muuissa käyttökohteissa olisi varmasti myös mahdollisuuksia. Kuminaöljyn haihtuvuuden vähentäminen formuloinnin avulla voi entisestään parantaa tehoa.

Sekundääaiaineiden tuotantokustannus Tuotantokustannusten arvioimista tehdään sitä mukaan, kun tarvittavia tietoja saadaan. Ketjun eri vaiheissa on vielä epävarmuustekijöitä, jotka voivat aiheuttaa virhearviointeja. Esimerkiksi morsingon lehtisadon tuottopotentiaali on todennäköisesti korkeammalla. Muuttuvista kustannuksista laskettuna raaka-aineiden hinta muodostanee 50 - $75 \%$ ja erotuskustannukset vähintään $25 \%$. Laitekustannusten hintaa emme ole laskeneet. Koko sekundääriainetuotannon kustannuksiin vaikuttaa myös sivutuotteiden mahdollinen hyödynnettävyys.

\section{Johtopäätökset}

Tutkimusten avulla olemme voineet edetä morsingon ja kuminan muodostamien sekundääriaineiden tuotteistamiseen vaadittavaa tuotantoketjua jo pitkälle. Olemme saaneet myös hyvän kuvan kasviaineiden soveltuvuudesta uusiin kohteisiin ja mahdollisiin tuotteisiin. Uusien käyttökohteiden löytäminen onkin tärkeimpiä tavoitteita uusien viljelykasvien tutkimuksessa. Silloin on myös perusteita jatkaa vielä selvittämättömiä viljelyteknisiäkin kysymyksiä.

Vaikka tutkimukset ovat kesken voimme todeta, että kasviaineiden erotusmenetelmiä voidaan kehittää maatilalle tai jopa vain maatiloille ja pk-yrityksiin soveltuviksi. Esimerkiksi kasvi-indigon eristys saattaa olla juuri sellaista toimintaa, mikä erityisesti sopii pienempiin yksiköihin. Tutkimukset luovat perustaa sille, ettei tulevaisuuden viljelijän tai maaseudun rooli ole enää pelkästään raaka-aineen tuottaja. Viljelijä, osuuskunta tai muu maaseudun yrittäjä voisi ryhtyä myös erikoiskasveista eristettävien kasviaineiden tuottajaksi. Maaseudun voimavaroina ovat kasvi- ja muut luonnonvarat, joista teknologian avulla voidaan näin luoda uusia bioalan toimintamuotoja.

Tuotantoketjussa uusien kasvien viljelystä sekundääriaineiden tuotteistamiseksi on kuitenkin vielä tehtävää. Seuraava askel on löytää tai luoda ennakkoluulottomia yrittäjiä, jotka ovat valmiita yhdessä tutkimuksen kanssa tekemään töitä aineiden tunnettavuuden edistämiseksi kysynnän aikaansaamiseksi sekä tuotteistamisen loppuunviemiseksi. Se miten tärkeäksi tulevaisuuden kuluttaja kokee kestävän kehityksen ja miten lumoavaksi hän kokee kasvivärien maailman, vaikuttavat haihtuvien öljyjen käyttöön luomuperunan rutonhallintaan sekä indigon käyttöön eko-design-tekstiileissä. 
Kuminan haihtuvasta öljystä torjunta-aineeksi

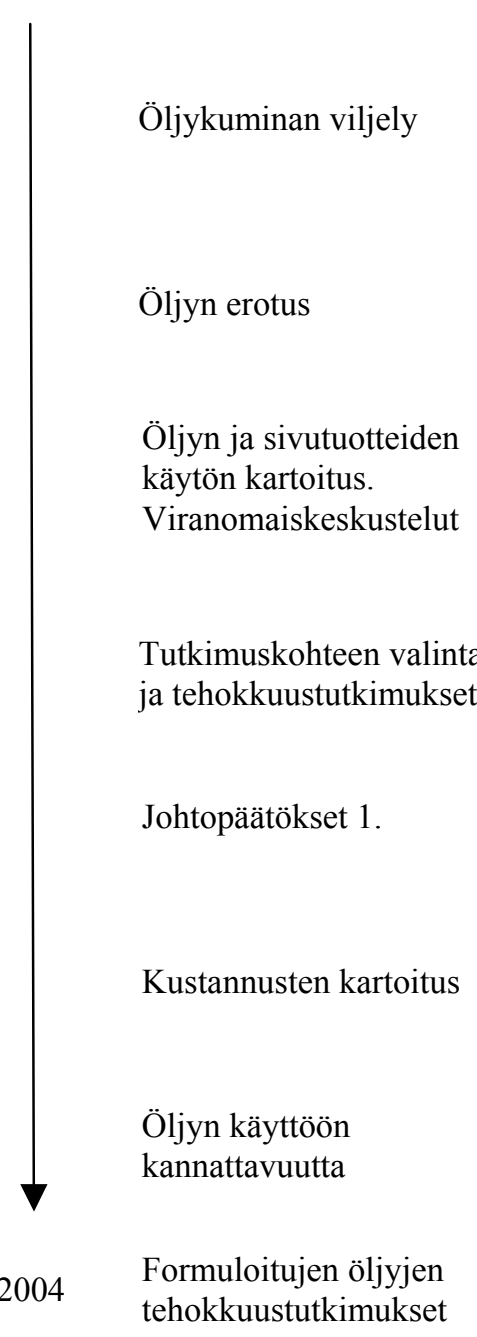

2005 Johtopäätökset 2.

\section{Kuminan haihtuvasta öljystä torjunta-aineeksi}

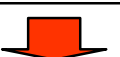

Bleija, Record, Sylvia satoisia ja öljypitoisia lajikkeita

Runsas N-lannoitus voi pienentää öljypitoisuutta

Yksivuotinen kumina on kaksivuotisen lisäksi

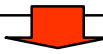

Öljyn erotus tislaamalla tai puristamalla.

Siemenestä öljyä ja sivutuotteita

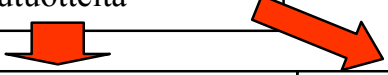

Öljyä puutavaran suojaukseen, rikkakasvien torjuntaan, vihannesten varastotauteihin, pikkuporsaiden ruokintaan, perunaruton torjuntaan
Sivutuotteissa fenoleita, kasvisteroleita, kasviöljyjä. Elintarvikkeeksi, rehuksi
Öljy luomuperunan perunaruttoa vastaan. Tehokkuustutkimukset laboratoriossa, kasvihuoneessa ja kentällä.

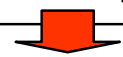

Viivästyttää ruttoepidemiaa -> Potentiaalia ruton hallitsemiseksi. Öljyjen haihtuvuus heikentää tehoa kenttäoloissa.

Kokeissa käytetyillä määrillä (1/ha), öljyn arvioidulla hinnalla (euro/l) ja luomuperunan kilohinnalla (euro/kg) öljyn käyttö ei ole tällä hetkellä kannattavaa

Öljyjen formulointia haihtumattomaksi. Vaikutuksen tehostaminen. Tehomekanismin ymmärtäminen. Öljyn eristyksen optimointia. Muut öljyn lähteet

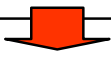

Tavoite: Öljy entistä tehokkaampaa ja pienemmät käyttömäärät.

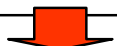

Formuloitujen öljyjen tehokkuus vs. taloudellisuus vs.

viranomaisvaatimukset. Öljystä torjunta-aine tai muu tuote.

Formuloitujen öljyjen käyttö jo aiemmin tutkituissa kohteissa.

Kuva 1. Kuminan haihtuvien öljyjen tuotantoketju kohti mahdollista tuotteistamista. 


\section{Kirjallisuus}

Alanen, H. \& Gröhn, A. 2003. Värimorsinko - Euroopan sininen kasviväri. Opinnäytetyö Vaate- ja tekstiilisuunnittelu, Muotoilun ja viestinnän koulutusohjelma, EVTEK Muotoiluinstituutti. $80 \mathrm{~s}$.

Balfour-Paul, J. 1998. Indigo. British Museum Press. ISBN 0714125504.

Hannukkala, A., Keskitalo, M., Laamanen, J. \& Rastas, M. 2001. Control of potato late blight with caraway and dill extracts. Potato late blight workshop, Edinburgh, UK, 26-30 September 2001.

Keskitalo, M. 2001. Effect of abiotic factors on the concentration of health-promoting secondary metabolites in crops grown in northern latitudes. World conference on medicinal and aromatic plants. Possibilities and limitations of medicinal and aromatic plants production towards the $21^{\text {st }}$ century, 8-1 $1^{\text {th }}$ July, 2001, Budapest Hungary, p 49.

Keskitalo, M. 2002a. Production of plant-derived dyes: the effect of nitrogen application on indigo concentration and yield in Nordic growth conditions. Abstract book, $5^{\text {th }}$ European Symposium Industrial Crops and Products, 24-26.4 2002 Amsterdam, the Netherlands, p 96.

Keskitalo, M. 2002b. Production and composition of antimicrobial extracts from caraway. Abstract book, $5^{\text {th }}$ European Symposium Industrial Crops and Products, 24-26.4 2002 Amsterdam, the Netherlands, p 95.

Mussaari, E. 2003. Sinisen tähden. Kasviperäisellä indigolla värjätyn villan väri ja värinkesto. Vertailu Isatis tinctorian, Indigofera tinctorian ja synteettisen indigon välillä. Käsityötieteen pro-gradu -tutkielma. Helsingin yliopisto, Kasvatustieteellinen tiedekunta, Kotitalous- ja käsityötieteiden laitos. 74 s.

Mäkinen, T. 2003. Väritattaren viljely ja indigon eristys. Ympäristöhoidon opinnäytetyö. Laurea-ammattikoulu, Hyvinkää-instituutti. $50 \mathrm{~s}$.

Oosterhaven, K., Poolman, B. \& Smid, E.J. 1995. S-Carvone as a natural sprout inhibiting, fungistatic and bacteristatic compound. Industrial Crops and Products 4: 23-31.

Sammallahti, J. 2001. Haihtuvan öljyn ja siemensadon muodostuminen eri kuminalajikkeilla. Kasvinviljelytieteen pro-gradu-työ. Helsingin yliopisto, Soveltavan biologian laitos. $79 \mathrm{~s}$.

Stoker, K.G., Cooke, D.T. \& Hill, D.J. 1998. An improved method for the large-scale processing of woad (Isatis tinctoria) for possible commercial production of woad indigo. J. agric. Engng. Res. 71:315-320

Vuorema, A., Roessler, A., Crettenand, D., Rys, P. \& Keskitalo, M. 2004. Electrochemical reduction of plantderived indigo from Isatis tinctoria L. Abstract. Colorchem, '04 Spindleruv Mlyn Tsekki 23.-27.5.-04.

Viljanen, K. 2004. Lämpötilan vaikutus indigon uuttumiseen värimorsingon (Isatis tinctoria) lehdistä. Opinnäytetyö, Laboratorioalan koulutusohjelma, Pirkanmaan ammattikorkeakoulu.

Westerback, S. 1999. Kuminaöljyn käyttö perunan idunestoaineena ja sienitautien estäjänä. Pro gradu -tutkielma Helsingin yliopisto Kasvibiologian laitos, Kasvipatologia. 57 s. 